\title{
THE PRESENCE OF ANTI-BORRELIA BURGDORFERI ANTIBODIES IN PERSON WITH SUSPECTED LYME DISEASE
}

\section{WYSTĘPOWANIE PRZECIWCIAŁ ANTY-BORRELIA BURGDORFERI U OSÓB Z PODEJRZENIEM BORELIOZY Z LYME}

\author{
Małgorzata Tokarska-Rodak ${ }^{1(A, B, C, D, E, F)}$, Dorota Plewik ${ }^{2(B, C, D, E)}$, \\ Barbara Gałecka $^{3(B)}$, Ryszard Domański ${ }^{3(B)}$ \\ ${ }^{1}$ Pope John Paul II State School of Higher Education in Biała Podlaska, Department of Health, Poland \\ ${ }^{2}$ Pope John Paul II State School of Higher Education in Biała Podlaska, Innovation Research Centre, Poland \\ ${ }^{3}$ Regional Specialist Hospital in Biała Podlaska, Poland
}

Authors' contribution Wkład autorów: A. Study design/planning zaplanowanie badań B. Data collection/entry zebranie danych

C. Data analysis/statistics dane - analiza i statystyki D. Data interpretation interpretacja danych E. Preparation of manuscript przygotowanie artykułu F. Literature analysis/search wyszukiwanie i analiza literatury G. Funds collection zebranie funduszy
Tables: 0

Figures: 4

References: 20

Submitted: 25.01 .2016

Accepted: 11.02 .2016

\section{Summary}

Background: Lyme disease is a multi-organ disease caused by spirochetes, Borrelia burgdorferi sensu lato, transmitted by Ixodes, with its clinical picture including involvement of the skin, joints, nervous system and heart. Laboratory diagnostic tests for Lyme disease are mainly based on the detection of anti-Borrelia burgdorferi antibodies by means of serological methods. Aim of the work: assessment of the level of antibodies against specific $B$. burgdorferi s.l. antigens in persons with suspected Lyme disease.

Material and methods: the tested group consisted of 98 patients with suspected Lyme disease. During the first phase of the tests, anti-Borrelia burgdorferi IgM/IgG antibodies were marked using ELISA method, and positive and uncertain results were confirmed by Westernblot test (Wb).

Results: anti-B. burgdorferi IgM/IgG antibodies were present in 60 patients (61.2\%). IgM and IgG antibodies were detected as positive in $8(8.1 \%)$ and $35(35.7 \%)$ patients respectively. IgM and IgG were co-present in 6 persons (6.1\%), including 2 persons (2\%) with positive results in both classes. All patients with positive IgM (12 persons) had anti-OspC antibodies, and 2 patients had, in addition, anti-p31 antibodies. In patients with positive IgG the results were as follows: antibodies against antigen p17 - 77\% of cases, VlsE - 74\%, p30 - 46\%, p39$44 \%$, p83 - 38\%, p19 - 31\%, OspC/p25-28\%, p31-23\%, p21-8\%.

Conclusions: laboratory diagnostic tests for Lyme disease must be performed in accordance with the current standards, positive and uncertain results must be confirmed by Westernblot test. Results of lab tests must correlate with patient's symptoms.

Keywords: Lyme disease, Borrelia burgdorferi, Western blot, VlsE

\section{Streszczenie}

Wprowadzenie: Borelioza z Lyme jest wielonarządową chorobą wywoływaną przez krętki Borrelia burgdorferi sensu lato, przenoszone przez kleszcze Ixodes, której obraz kliniczny wiąże się z zajęciem skóry, stawów, układu nerwowego i serca. Diagnostyka laboratoryjna boreliozy z Lyme opiera się głównie na wykrywaniu przeciwciał anty-Borrelia burgdorferi metodami serologicznymi. Cel pracy: ocena poziomu przeciwciał dla specyficznych antygenów B. burgdorferi s.l. u osób z podejrzeniem boreliozy z Lyme.

Materiały i metody: grupę badaną stanowiło 98 pacjentów z podejrzeniem boreliozy z Lyme. W pierwszym etapie wykonano oznaczenie przeciwciał IgM/IgG anty-Borrelia burgdorferi metodą ELISA, a wyniki pozytywne i graniczne potwierdzono testem Western blot (Wb).

Wyniki: obecność przeciwciał IgM/IgG anty-B. burgdorferi wykazano u 60 pacjentów $(61,2 \%)$. Przeciwciała tylko w klasie IgM oraz tylko IgG na poziomie dodatnim stwierdzono odpowiednio u $8(8,1 \%)$ oraz $35(35,7 \%)$ pacjentów. Współistnienie IgM i IgG stwierdzono u 6 osób $(6,1 \%)$, w tym u 2 (2\%) na poziomie dodatnim w obu klasach. U wszystkich pacjentów z pozytywnym wynikiem w klasie IgM (12 osób) obecne były przeciwciała anty-0spC, u 2 pacjentów dodatkowo obecne były przeciwciała anty-p31. U pacjentów z pozytywnym wynikiem w klasie IgG uzyskano następujące wyniki: przeciwciała przeciwko antygenowi p17 - 77\% przypadków, VlsE - 74\%, p30 - 46\%, p39 - 44\%, p83 - 38\%, p19 - 31\%, 0spC/p25$28 \%$, p31 - 23\%, p21 - 8\%.

Wnioski: prowadząc diagnostykę laboratoryjną boreliozy z Lyme należy postępować zgodnie z obowiązującymi standardami, wyniki dodatnie i graniczne uzyskane metodą ELISA, należy potwierdzić testem Western blot. Wyniki badań laboratoryjnych muszą korelować z objawami występującymi u pacjenta.

Słowa kluczowe: borelioza z Lyme, Borrelia burgdorferi, Western blot, VlsE

Tokarska-Rodak M, Plewik D, Galecka B, Domanski R. The presence of anti-Borrelia burgdorferi antibodies in person with suspected Lyme disease. Health Problems of Civilization 2016; 10(3): 15-20. doi: 10.5114/hpc.2016.61362.

Address for correspondence / Adres korespondencyjny: Małgorzata Tokarska-Rodak, Pope John Paul II State School of Higher Education in Biala Podlaska Department of Health, 102 Sidorska Street, 21-500 Biała Podlaska, Poland, e-mail: rodak.malgorzata@gmail.com, phone: +48 83 344 9918

Copyright: (C) 2016 Pope John Paul II State School of Higher Education in Biała Podlaska. This is an Open Access journal, all articles are distributed under the terms of the Creative Commons Attribution-NonCommercial-ShareAlike 4.0 International (CC BY-NC-SA 4.0) License (http://creativecommons.org/licenses/by-nc-sa/4.0/), allowing third parties to copy and redistribute the material in any medium or format and to remix, transform, and build upon the material, provided the original work is properly cited and states its license. 


\section{Introduction}

Lyme disease is a multi-organ disease caused by spirochetes, Borrelia burgdorferi sensu lato, transmitted by Ixodes, with its clinical picture including involvement of the skin, joints, nervous system and heart [1]. Borrelia burgdorferi sensu lato complex includes 18 genospecies of varied pathogenicity. $B$. burgdorferi sensu stricto, $B$. garinii, B. afzelii and B. bavariensis are considered in Europe as transparently pathogenic and responsible for the production of clinical signs. However, the presence of DNAs of other potentially pathogenic species, such as $B$. valaisiana, $B$. bissettii, $B$. spielmanii, was revealed in clinical specimens taken from patients with Lyme disease symptoms, which proves their importance in the development of clinical manifestation of the infection $[2,3,4]$. B. lusitaniae role in the development of Lyme disease remains difficult to determine, given the fact that clinical signs of the infection do not correspond with the known signs of Lyme disease.

Early local clinical manifestation of Lyme disease includes the presence of an expanding area of redness (erythema migrans, EM), that appears at the site of a tick bite within 3 to 30 days after the bite has occurred, or less frequently the presence of multiple areas of redness (multiple erythema). Ery thema can be the only symptom of the developing Borrelia burgdorferi infection, but it can also be concomitant with flu-like symptoms such as fever, headaches, muscle aches and joint pains [2,5]. Erythema migrans has a diagnostic value and does not require laboratory tests to confirm it, for anti-B. burgdorferi antibodies are not present at that time and negative result of the tests can lead to erroneous diagnosis. Anti- $B$. burgdorferi antibodies appear after 3-4 weeks from the occurrence of EM [6]. Other early symptoms of Lyme disease include early Lyme neuroborreliosis (meningoradiculitis, meningitis, paralysis of the 7th cranial nerve and other cranial nerves), Lyme carditis, Lyme arthritis. Early symptoms of Lyme disease are concomitant with the presence in the serum of $\operatorname{IgM}$ or IgM/IgG antibodies against specific antigen proteins of $B$. burgdorferi [2,5]. If Lyme disease is not treated early it may produce late stage changes including Lyme neuroborreliosis (encephalomyelitis, radiculoneuritis, meningitis, occlusive vasculitis), Lyme arthritis, synovitis and atrophic inflammation of the skin, usually of the hands and feet (Acrodermatitis chronica athrophicans, $A C A$ ). The presence of anti-B. burgdorferi IgG antibodies in the serum accompanies the late stage symptoms of the disease.

Results of serological tests carried out in cases of Lyme disease patients with dominating arthralgia and/ or arthritis symptoms, treated symptomatically and with etiotropic antibiotic therapy, indicate the possibility of infection with several species of B. burgdorferi s.l. [9]. Diversity of Borrelia burgdorferi s.l. genospecies must be taken into consideration in the selection of diagnostic tests for patients from a given geographical area, development of new diagnostic tests and diagnostic antigens for serological tests [6].

Two-phase approach in diagnostics of B. burgdorferi s.l. infections, recommended by European Concerted Action on Lyme Borreliosis (EUCALB) and Center for Disease Control and Prevention (CDC), has been introduced to limit the occurrence of cross reactions and false positive results $[10,11]$. ELISA test is a preliminary test, whereas Western-blot (Wb) test confirms the specificity of a positive or an uncertainly positive result of ELISA test. Wb test cannot be used independently from the first phase of the diagnostic examination [6]. Serological tests determining the level of anti-Borrelia burgdorferi IgM/IgG antibodies cannot be used in the evaluation of treatment effectiveness. Effectiveness of antibiotic therapy should be assessed only on the basis of the dynamics of a clinical picture [1]. Anti-B. burgdorferi antibodies can be detected despite proper antibiotic therapy and elimination of clinical signs, and their presence, however, does not prove the continuance of the disease and must be considered in correlation with signs [12].

\section{Aim of the work}

The work aimed at assessing the level of antibodies against specific B. burgdorferi s.l. antigens in persons with suspected Lyme disease.

\section{Material and methods}

The tested group consisted of 98 patients of the Clinic of Infectious Diseases and the Clinic and Neurological Department of Regional Specialist Hospital in Biala Podlaska with suspected Lyme disease. The tested group comprised 60 women aged 17 to 81 years (mean: 56, SD: 14.7) and 38 men aged 16 to 76 years (mean: 52, SD: 15.1). The tested patients usually informed of painful joints (87 patients), while 4 of them had other symptoms such as: bone pains, muscle aches, headaches, numbness. 11 patients informed of symptoms other than joint pains, namely headaches and paresis.

Diagnostics of Lyme disease was carried out in accordance with the current standards. During the first phase of the tests, anti-Borrelia burgdorferi IgM/IgG antibodies were marked using ELISA method, and positive 
and uncertain results were confirmed by Western-blot test (Wb). ELISA test (Euroimmun) contained a mix of B. burgdorferi s.s., B. afzelii, B. garinii antigens and recombinant VlsE protein. Western-blot test (Euroimmun) contained B. afzelii (p83, p41, p39/BmpA, p31/OspA, p30, p25/OspC, p21, p19, p17/DbpA) antigens and recombinant VlsE antigen. The tests were carried out as instructed by the manufacturer.

\section{Results}

Two-phase diagnostics showed the presence of anti-B. burgdorferi IgM/IgG antibodies in 60 patients (61.2\%) and the lack of anti-B. burgdorferi antibodies in 38 tested patients (38.8\%). Anti-B. burgdorferi IgM and IgG antibodies were present in tested patients in different distributions. 8 patients (8.1\%) had positive IgM test results, whereas 35 tested patients (35.7\%) had positive IgG test results. IgM and IgG were co-present in 6 persons (6.1\%), but only 2 patients (2\%) had both IgM and IgG at the level considered as positive (fig. 1). Figure 2 presents results of diagnostic tests with reference to symptoms reported by patients.

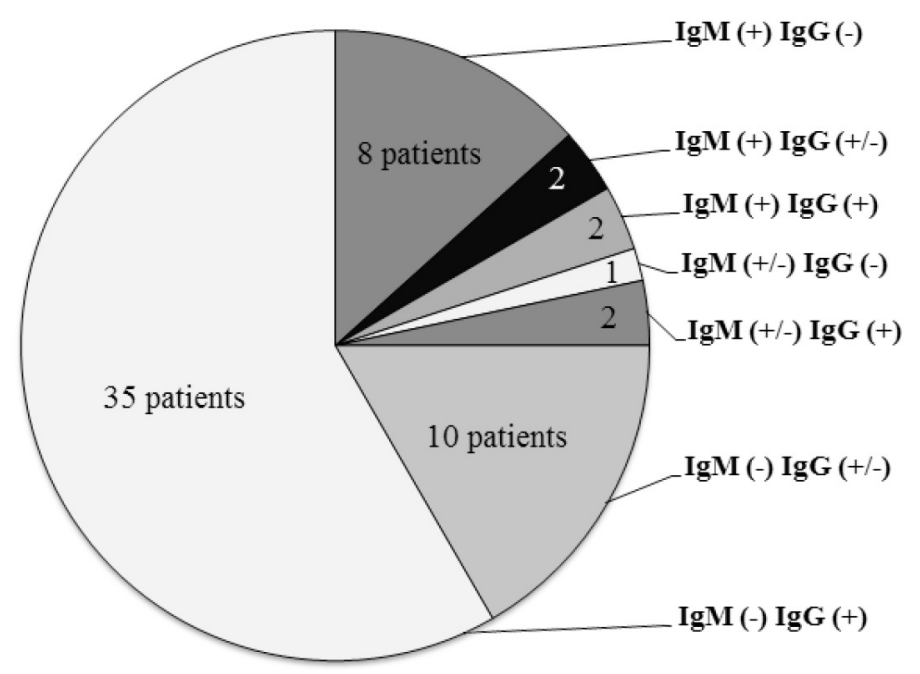

Figure 1. Results of Western blot test performed among patients with suspicion of Lyme disease $(+)$ positive, (+/-) borderline, (-) negative

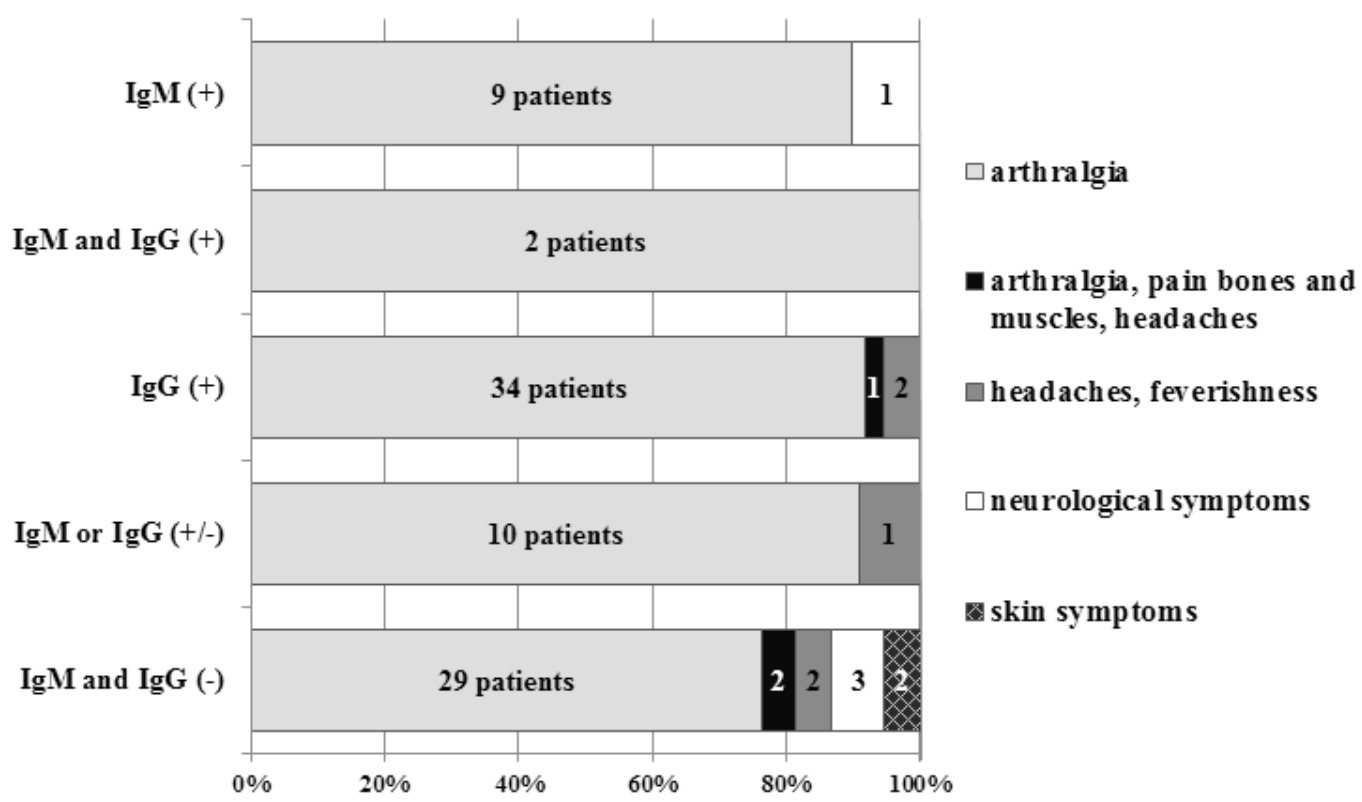

Figure 2. Results of diagnostic tests of Lyme disease with reference to symptoms reported by patients $(+)$ positive, $(+/-)$ borderline, $(-)$ negative 
Analysis of the prevalence of antibodies against specific antygens was performed in patients with positive Wb test results. All patients with positive IgM (12 persons) had anti-OspC antibodies, and 2 patients had, additionally, anti-p31 antibodies. Figure 3 provides a graphical representation of the above data.

\begin{tabular}{|c|c|c|c|c|}
\hline $\begin{array}{l}\text { Number } \\
\text { of bands }\end{array}$ & \multicolumn{2}{|c|}{ Antigens - IgM Western blot } & \multicolumn{2}{|c|}{ Number of patients } \\
\hline 1 band & OspC & $\longrightarrow$ & $10(83 \%)$ & \\
\hline 2 bands & OspC & $\longrightarrow$ & $2(17 \%)$ & $0 \%)$ \\
\hline
\end{tabular}

Figure 3. Positive results of Western blot test in class IgM

Antibodies against p17 antigen - 77\% of cases and against VlsE antigen - 74\% of cases were usually present in patients with positive IgG test results. Less frequently present were antibodies against antigen p30 (46\%), p39 (44\%), p83 (38\%), p19 (31\%), OspC/p25 (28\%), p31 (23\%) and p21 (8\%). Figure 4 presents detailed data.

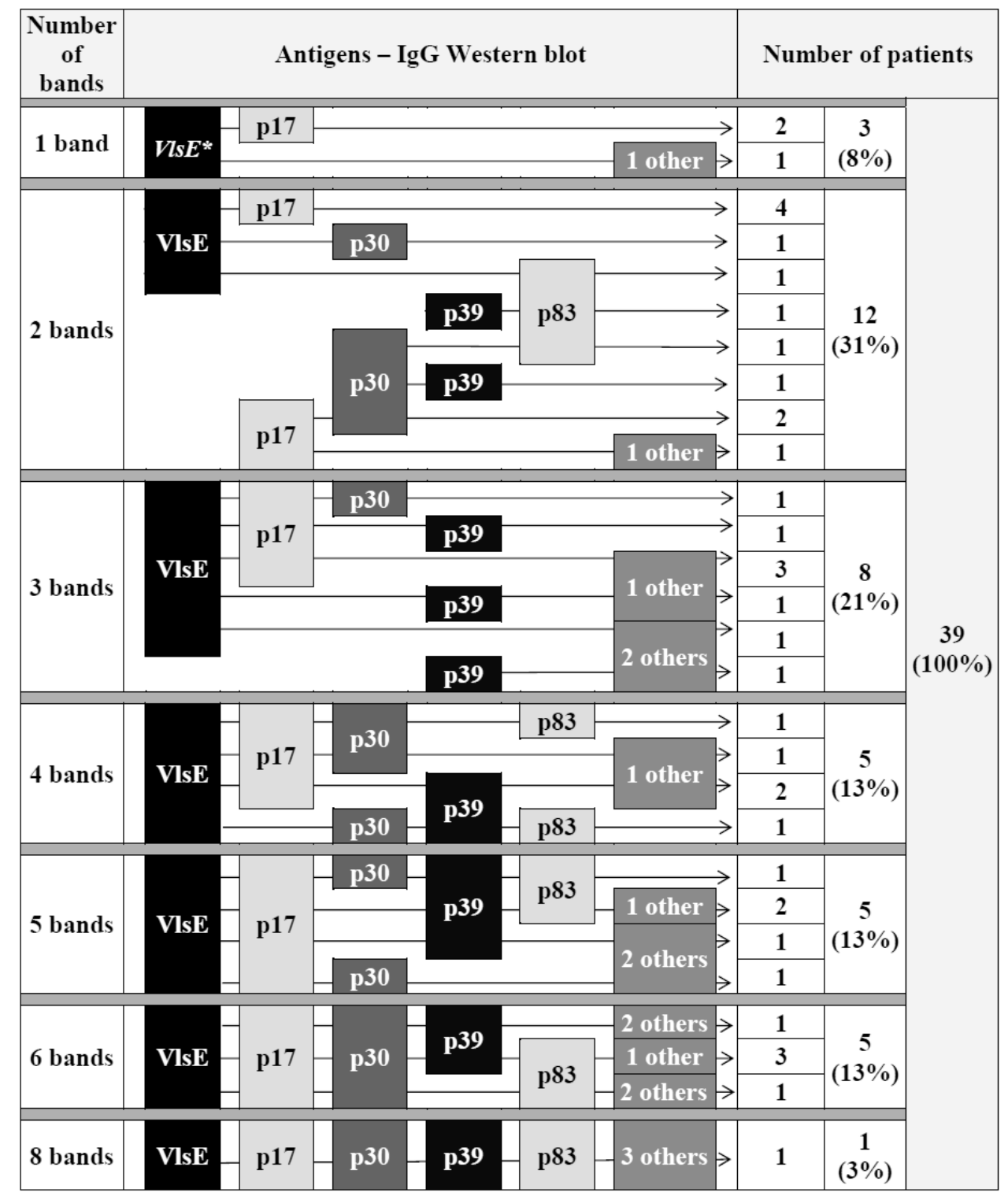

Figure 4. Positive results of Western blot test in class IgG

* - borderline band

others: p19, p21, OspC (p25), p31 


\section{Discussion}

Interpretation of serological test results in persons with suspected Lyme disease should be connected with clinical signs observed in patients. It is essential to include information on duration of the disease as being closely connected with the appearance of antibodies against specific antigens. Antibodies specific for B. burgdorferi were not detected in $38.8 \%$ of tested patients with suspected Lyme disease, despite the presence of clinical signs that could have been related to infection with $B$. burgdorferi. Patients mainly reported joint pains, which may suggest the existence of other than infection with $B$. burgdorferi causes for the appearance of clinical signs, namely reactive arthritis, infectious arthritis or rheumatoid arthritis [13].

Recommendations of the 2014 Working Group pointed out that "Serological tests are the basis for the laboratory diagnosis of Lyme disease. If, however, despite negative laboratory test results, a doctor still suspects, based on clinical signs, late stage Lyme disease, he may employ other, additional diagnostic methods, such as detection of spirochete DNA (PCR) or culture. They are also applicable in patients with atypical erythema migrans, with suspected early Lyme neuroborreliosis, in which antibodies has not been formed yet, and in patients with decreased immunity" [6]. Negative results of serological tests may also be obtained in cases where symptoms of infection are short-term, in acute Lyme neuroborreliosis with a short duration of the disease, or in cases where an early antibiotic therapy has been initiated. In such cases, repetition of tests should be considered.

The presence of IgM anti-OspC and anti-p41 is mainly detected in patients with an early manifestation of the disease, whereas lipoprotein OspC is considered in diagnostics of Lyme disease as a marker of early $B$. burgdorferi infection [11]. The presence of antibodies against OspC antigen was detected during own tests in all patients with positive IgM.

Diagnostic importance of OspC decreases in the course of the development of immune response to infection with B. burgdorferi s.l., when there is an increased production of IgG antibodies against many spirochetal protein antigens, including p83/100, p53, p58, p43, p39, p31, p30, p21, DbpA/p17, p19 [11,14,15]. However, DbpA/p17, p83/100, p39 antigens as well as specific recombinant antigens like VlsE and VlsE C6 peptide are regarded as immunodominant antigens in the late response to B. burgdorferi $[6,16,17]$. Results of the tests confirm the diagnostic importance of p17 and VlsE, for which IgG was detected exceptionally often, in $77 \%$ and $74 \%$ of cases respectively. The presence of IgG anti-p30 (46\%), anti-p39 (44\%) and anti-p83 (38\%) also indicates their crucial importance in diagnostics of Lyme disease.

In patients with a clinical manifestation of joint Lyme disease, besides IgG antibodies against VlsE, also IgG against other in vivo antigens, such as BBA36, BB0323, CRASP3 and pG, were detected [18,19,20]. In the lack of IgG antibodies, late stage Lyme disease cannot be taken into consideration. The presence of IgM antibodies and the lack of positive results for IgG antibodies do not diagnostically confirm the late stage of the disease [2,12]. The presence of antibodies themselves, with no signs of infection, is not an indication to initiate treatment [6].

\section{Conclusions}

Titres of anti-B. burgdorferi IgM/IgG antibodies obtained in ELISA test, indicating positive or uncertain results in diagnostics of Lyme disease, cannot be the only indicant taken into account in making a decision to initiate a treatment. Positive and uncertain results must be confirmed by Western-blot test. In diagnostics of Lyme disease the co-existence of specific anti-B. burgdorferi antibodies with clinical signs of infection must be taken into consideration.

\section{References:}

1. Flisiak R, Pancewicz S. Diagnostyka i leczenie Boreliozy z Lyme zalecenia Polskiego Towarzystwa Epidemiologów i Lekarzy Chorób Zakaźnych [Internet] [cited 2015 Dec 10]. Available from: http://www. pteilchz.org.pl/data/standardy/borelioza_z_lyme_2011.pdf (in Polish).

2. Pancewicz SA, Garlicki AM, Moniuszko-Malinowska A, Zajkowska J, Kondrusik M, Grygorczuk S, et al. Diagnosis and treatment of tick-borne diseases recommendations of the Polish Society of Epidemiology and Infectious Diseases. Przegl Epidemiol. 2015; 69: 309-316.

3. Aguero-Rosenfeld ME, Wang G, Schwarz I, Womser GP. Diagnosis of Lyme borreliosis. Clin Microbiol Rev. 2005; 18(3): 484-509.

4. Ruderko N, Golovchenko M, Ruzek D, Piskunova N, Mallatova N, Grubhoffer L. Molecular detection of Borrelia bisettii DNA in serum samples from patients in the Czech Republic with suspected borreliosis. FEMS Microbiol Lett. 2009; 292: 274-81. 
5. Stanek G, Fingerle V, Hunfeld KP, Jaulhac B, Kaiser R, Krause A, et al. Lyme borreliosis: Clinical case definitions for diagnosis and management in Europe. Clin Microbiol Infect. 2011; 17(1): 69-79.

6. Chmielewski T, Dunaj J, Gołąb E, Gut W, Horban A, Pancewicz S, et al. Diagnostyka laboratoryjna chorób odkleszczowych. Diagnosta Laboratoryjny. 2014; 36(3): 9-22 (in Polish).

7. Bratton RL, Whiteside JH, Hovan MJ, Engle RL, Edwards FD. Diagnosis and treatment of Lyme Disease Mayo Clin Proc. 2008; 83(5): 566-571.

8. Dinser R, Muller-Ladner U. Lyme arthritis: a European perspective. CML Rheum. 2007; 117(4): $101-108$.

9. Tokarska-Rodak M, Fota-Markowska H, Kozioł-Montewka M, Śmiechowicz F, Modrzewska R. The detection of specific antibodies against B. burgdorferi s.s., B. afzelii, B. garinii and B. spielmanii antigens in patients with Lyme disease in Eastern Poland. New Med 2010; 14(3): 84-87.

10. Center for Disease Control and Prevention [Internet] [cited 2015 Dec 10]. Available from: http://www.cdc. gov/lyme/.

11. European Concerted Action on Lyme Borreliosis [Internet] [cited 2015 Dec 10]. Available from: http://www. eucalb.com/.

12. Wilske B, Fingerle V, Schulze-Spechtel U. Microbiological and serological diagnosis of Lyme boreliosis. FEMS Immunol Med Microbiol. 2007; 49: 13-21.

13. Flisiak R, Szechiński J. Choroby przenoszone przez kleszcze. In: Szczeklik A. Choroby wewnętrzne. Stan wiedzy na rok 2010. Kraków: Medycyna Praktyczna; 2010. p. 2289-98 (in Polish).

14. Coburn J, Leong J, Chaconas G. Illuminating the roles of the Borrelia burgdorferi adhesins. Trends Microbiol. 2013; 21(8): 372-379.

15. Witecka-Knysz E, Klimczok M, Lawka K, Zajkowska J, Pancewicz S, Kondrusik M, et al. Borelioza: dlaczego diagnostyka jest taka trudna? Diagnosta Laboratoryjny. 2007; 13(1): 11-13 (in Polish).

16. Bacon RM, Biggerstaff BJ, Schriefer ME. Serodiagnosis of Lyme disease by cinetic enzyme-linked immunosorbent assai using recombinant Vlse or peptide antigens of Borrelia burgdorferi compared with 2-tiewred testing using whole -cell lysates. J Infect Dis. 2003; 187: 1187-1199.

17. Robertson J, Guy E, Andrews N, Wilske B, Anda P, Granström M, et al. European Multicenter Study of Immunoblotting in Serodiagnosis of Lyme Borreliosis. J Clin Microbiol. 2000; 38: 2097-2102.

18. Hofmann H, Wallach R, Lorenz I, Bechtel M. Comparison of a New line assay using purified and recombinant antigens with a European lysate blot for serodiagnosis of Lyme borreliosis. IJMM. 2006; 296: 288-290.

19. Tokarska-Rodak M, Fota-Markowska H, Śmiechowicz F, Gajownik B, Prokop M, Modrzewska R, et al. Antibodies against in vivo B. burgdorferi antigens evaluated in patients with Lyme arthritis with reference to treatment. Adv Clin Exp Med. 2010; 19(4): 489-496.

20. Tokarska-Rodak M, Kozioł-Montewka M, Fota-Markowska H, Bielec D, Modrzewska R, Pańczuk A. Frequency and specificity of the antibodies against Borrelia burgdorferi tested by Western blot method in patients with symptoms of arthritis. Cent Eur J Immunol. 2008; 33(4): 220-223. 